\title{
US national labs face changing roles
}

\section{Washington}

THE three US nuclear weapons laboratories - Los Alamos, Lawrence Livermore and Sandia - can rest easy now, at least for a while. Last month, President George Bush signed into law a 1992 budget for the labs which avoided proposed cuts that would have, according to the lab directors, jeopardized their ability to perform their basic job: to develop state-of-the-art nuclear warheads.

But the debate over the laboratories' future is far from over. As the perceived nuclear threat from the Soviet Union continues to diminish and as pressures mount to trim the federal deficit, budget makers are likely to view the laboratories as one place where cuts can be made. In response, the laboratories and the Department of Energy (DOE), which runs them, are taking a new look at what the laboratories' national security role should be in this changing world.

In a few weeks, the DOE will release a report from a special task force on the national laboratories that addresses this question. The report will recommend that the laboratories apply the expertise of their 9,000 scientists and engineers who develop nuclear weapons in new and different ways, from designing a new generation of safer warheads to assisting in verification of arms control treaties and helping in the development of a smaller, environmentally friendly nuclear weapons production complex. The waning of the Cold War is modifying what the nation asks of its nuclear weapons scientists, and the change is coming fast.

\section{Clean-up squeezes budget}

Historically, the budget for nuclear weapons work at the laboratories has moved up and down with the tide of nuclear politics. The most recent high tide came in 1987, after the Strategic Defense Initiative had pumped hundreds of millions of dollars into the laboratories' core nuclear weapons work, referred to as Research, Development \& Technology (RD\&T). Since then, according to Tony Lane, director of DOE's office of programme analysis and financial management, a 12 per cent decline in funding has forced the laboratories to cut their RD\&T workforce from 11,150 positions in 1987 to 8,900 estimated for 1992 .

And it could have been worse. If the budget submitted to the Office of Management and Budget in the autumn of 1990 had passed, another 500 RD\&T workers would have lost their jobs, says Richard Claytor, assistant secretary of defence programmes at DOE. But Sen. Pete Domenici - who represents New Mexico, home to Los Alamos and Sandia - persuaded the Senate Appropriations
Committee to give the DOE another $\$ 200$ million for its nuclear weapons work, bringing the total RD\&T budget to $\$ 1,945$ million.

Without that $\$ 200$ million injection, the laboratories' baseline competence in developing nuclear weapons would have been threatened, Claytor says. "We are now approaching a point where further reductions in the population of nuclear specialists can be harmful."

Nonetheless, DOE itself had submitted the original budget that department and national lab officials now say would have menaced nuclear weapons competence, and the reasons for that decision offer a telling insight into the conflicting pressures the laboratories are facing.

While RD\&T budgets have been dropping, the DOE's environmental budget propelled by the necessity of cleaning up the nuclear weapons manufacturing complex - has been swelling. In just two years, from 1990 to 1992, DOE's budget for waste management and environmental restoration doubled from $\$ 2,300$ million to $\$ 4,600$ million. At the same time, congressional budget agreements aimed at bringing the federal deficit under control have put a cap on the total annual DOE budgets. Because many of the environmental cleanups are mandated by law, DOE is forced to find cuts elsewhere in its budget, and RD\&T was one of them for fiscal year 1992.

Domenici, supported by DOE and laboratory officials, argued that the RD\&T cuts would be debilitating to the laboratories' nuclear design capabilities, and he convinced the Pentagon and Congress to agree to transfer $\$ 200$ million from the Department of Defense budget to DOE's nuclear weapons budget.

Nevertheless, the national laboratories' nuclear weapons work is likely to continue to be squeezed between the budget cap and the growing environmental expenses. And it is a catch-22 in more ways than one. One congressional staff member familiar with the situation characterized it as a power struggle between congressional committees: "The environmental committees are fighting the armed services committees [which oversee the nuclear weapons budgets] for jurisdiction over cleanup. No one on the armed services committees wants the environmental committees to have authority over the weapons plants." But the price of protecting the nuclear weapons complex from the environmental committees is to watch cleanup costs eat up an increasingly large part of the DOE budget.

Meanwhile, officials at DOE and the nuclear weapons laboratories are attempting to redefine what the laboratories' roles should be in a world that is less worried about nuclear war. All three of the laboratories have assignments unrelated to nuclear weapons development, but the weapons work is the core and the raison d'etre for each of them and accounts for approximately half of each of their budgets.

\section{New directions}

When the Secretary of Energy Advisory Board, a panel formed of prominent nonDOE scientists to counsel Secretary of Energy James Watkins, releases an interim report on the role of the laboratories in the next few weeks, it is likely to recommend expanded roles for them in several areas. The recommendations, which were discussed briefly in a public hearing by the board in July, will include:

Researchers at Los Alamos, Livermore and Sandia should play a major role in the clean-up of the nuclear weapons production complex. This will continue to be a growing part of DOE's job, and the nuclear weapons laboratories - with their expertise in nuclear physics and radioactivity are natural places to do much of the research.

The laboratories should help in developing a new nuclear weapons production complex. The DOE has set a goal of achieving a new complex that is more compact, less expensive and generates less nuclear waste than the current decades-old complex, but Siegfried Hecker, director of Los Alamos National Laboratory, notes that with the departure of such long-time contractors as Du Pont and Dow, the DOE has lost much of the expertise in the production complex. This leaves the laboratories as the natural - and sometimes the only - recourse. "Where else are you going to go for plutonium processing R\&D?" Hecker asks.

- The issues of nuclear non-proliferation, nuclear arms control and treaty verification are likely to take on increasing importance in coming years, and the laboratories - which already do some research on the technical aspects of these matters - are again the natural place to spend the extra money.

The laboratories should turn their nuclear weapon design efforts toward making nuclear weapons safer - less likely to release radioactive materials in case of such accidents as fires or plane crashes. Weapons designers say the warheads are already quite safe, but as the likelihood decreases that they will ever be used, the safety of the weapons becomes more important relative to their explosive power, and these changing priorities argue for redesigned warheads.

One issue that is likely to come up again and again is: Is the present duplication in the laboratories' nuclear design 
efforts justified? As those efforts are now set up, both Los Alamos and Lawrence Livermore perform basic design work, while Sandia has a support role - putting together the electronics and other parts of bombs so that they work as planned. Some argue that the country does not need two nuclear weapons laboratories that are doing the same job.

\section{Checks and balances}

DOE and laboratory officials disagree vigorously. "Having two design labs that can balance each other and check each other is very important," says Claytor at DOE. The two laboratories have a history of approaching problems very differently (which is often traced back to the differences and competition between the founding figures Robert Oppenheimer at Los Alamos and Edward Teller at Livermore), and these varying approaches and competitive spirit provide an effective method of peer review in a field that otherwise would have none. "As the number of nuclear tests decreases, the country still has to answer questions about its nuclear forces," says John Nuckols, director of Lawrence Livermore, but with only one lab, there would be no way to settle disputes over weapons design.

The question of whether to pay for two laboratories really depends on how good the United States wants its nuclear arsenal to be, notes Roy Woodruff, formerly associate director for Nuclear Design at Livermore and now a staff scientist at Los Alamos. "If your national policy is minimal deterrence, then one lab may be enough. If you're trying to keep a competitive edge over a very capable adversary, you need something more."

Although Congress answered that question last month by voting the extra $\$ 200$ million to keep nuclear design work healthy at both laboratories, this is unlikely to be the final word. Claytor says he foresees "stability" in the RD\&T budget in coming years, but this is going to be difficult to obtain unless the growing environmental costs level off.

Woodruff says that he, like many nuclear weapons designers, has always hoped that eventually he would work himself out of a job - that nuclear deterrence would hold off war long enough for peace to be kept by other methods, and nuclear weapons would not be needed. Although this seems unlikely to happen soon, still an increasing number of weapons designers could find themselves out of work as the nation decides it has less need to continuously upgrade its arsenal. And one way or another, the laboratories are in for a decade of unprecedented change, and their new courses are going to be set by decisions made in the next couple of years.

Robert Pool

\section{Will milk shake up industry?}

\section{Washington}

THE times they are a-changing, down on the farm. Ever since researchers demonstrated the tissue-specific expression of several types of foreign proteins in the milk of transgenic mice, the race has been on to scale up the technology to dairy livestock, where the capacity for highvolume production has obvious appeal.

Now in a significant technological advance, three separate research groups from the United Kingdom, the United States and the Netherlands have made considerable progress in this regard in sheep, goats and dairy cows. The research, reported in the September issue of Bio/Technology,

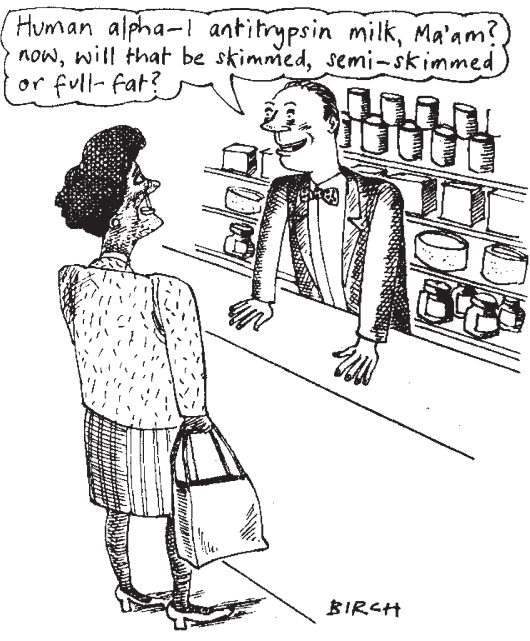

brings the biotechnology industry one step closer to the goal of providing a cheaper means of producing proteins than conventional expression systems.

Success with larger animals was first reported in 1989 by Agriculture and Food Research Council (AFRC) researchers at the Institute of Animal Physiology and Genetics Research in Edinburgh, Scotland. Although the Edinburgh team produced transgenic sheep that secreted human antihaemophilic factor IX and human $\alpha_{1}$ antitrypsin in their milk, expression levels were low.

Building on this, a joint project between Alan Coleman and colleagues at Pharmaceutical Proteins Limited and researchers at the Edinburgh institute produced five transgenic sheep - four females and one male - into which the human $\alpha_{1}$ antitrypsin gene had been incorporated. Following mating and breeding of three of the females, milk from all three contained human $\alpha_{1}$ antitrypsin at levels of greater than 1 gram per litre, and, in one case, levels of up to 35 grams of human $\alpha$ antitrypsin.

Researchers at Tufts University in Massachusetts and at the Massachusettsbased biotechnology company Genzyme Corporation have developed the first transgenic goats to produce tissue plasminogen activator (tPA) in their milk. Although the level of production - about 3 micrograms of tPA per millilitre of milk - is not economically realistic, Karl Ebert, director of experimental biotechnology at Tufts, says he has recently produced another transgenic goat in which the levels were increased a thousand-fold.

From a commercial standpoint, the dairy cow is the animal of choice. Dairy cows can produce 10,000 litres of milk annually, as compared to sheep and goats, whose milk yields can vary from 250 to 800 litres a year, depending on the breed. But historically, efforts to produce transgenic dairy cows have been thwarted because of cumbersome and costly surgical procedures. Now, however, researchers from Gene Pharming Europe (Leiden), the University of Leiden and the Research Institute for Animal Production (Zeist) have circumvented the need for the surgical removal and transfer of embryos by combining gene transfer with an in vitro embryo production system.

Jonathan MacQuitty, president and chief executive officer of GenPharm International, Inc., Gene Pharming's parent company, says GenPharm plans to use the technology to produce hLF, a human milk protein with antibacterial and iron transport properties, for infant formula preparations and as an oral treatment for immunocompromised patients. The company also intends to produce other proteins, which, like hLF, would be difficult or impossible to produce efficiently by other means.

Diane Gershon

\section{TELECOMMUNICATIONS}

\section{Pandolfi boosts HDTV}

\section{London}

IN hopes of encouraging European electronics companies and broadcasters to support new High Definition Television (HDTV) technology, the European Communities (EC) are planning to double their subsidies next year, EC minister for research and telecommunications Filippo Pandolfi announced last week. In a new five-year HDTV strategy that is to begin in 1992 , the $E C$ will spend a total of 1,000 million ecu (\$1,200 million) - 200 million ecu per year - on the broadcasting industry in hopes that a successful launch of HDTV by 1994 will rescue the fading European television and electronics industry. But Pandolfi has an uphill battle for European acceptance of HDTV; a new study by the accounting firm Coopers and Lybrand finds that switching to the new standard will cost consumers 21,000 million ecu $(\$ 25,000$ million) in the next 10 years to upgrade their receiving equipment. Christopher Anderson 